\title{
Lending Policies and Credit Administration in Pre-colonial Nigeria: A Case Study of Kundila of Kano
}

\author{
Dr. Lawal Bello Dogarawa \\ Department of Planning, Research \& Data Management Services \\ Nigerian Maritime Administration and Safety Agency (NIMASA) \\ NMRDC Complex, Kirikiri, Lagos, Nigeria \\ Tel: 234-809-924-4001Ｅ-mail: lbdogarawa@yahoo.com
}

\author{
Received: September 23, 2011 \\ Accepted: October 25, $2011 \quad$ Published: February 1, 2012 \\ doi:10.5539/ijef.v4n2p196 \\ URL: http://dx.doi.org/10.5539/ijef.v4n2p196
}

\begin{abstract}
This Paper studies the canons of lending and credit administration methods in the pre-colonial informal financial sector taking a case study of Kundila a famous $19^{\text {th }}$ Century trader in Kano City. Using desk research and interview techniques, the study finds similarities in both the lending principles and credit management styles in the pre-colonial informal setting and the modern financial institution's practices. However, Islamic legal system in the $19^{\text {th }}$ Century has helped to quicken administration of justice on cases of loan default as against secular laws that tend to cause delay in modern Nigeria. There was also intensive monitoring of loan and cases of auction of collateral or other severe measures against loan defaulters. The paper concludes that modern financial sector can learn from the leasing methods of Kundila so as to accord small and medium scale enterprises the opportunity of acquiring sophisticated machineries and equipment. This will increase aggregate production and assist government in achieving food security as well as rapid economic growth and development in the economy.
\end{abstract}

Keywords: Informal, Kundila, Lending, Leasing, Administration, Monitoring, Nigeria

\section{Introduction}

As the centre of commerce even today, Ferguson (1973) describes Kano as the wealthiest and most important manufacturing and commercial city in the $19^{\text {th }}$ Century in Hausaland. With a stable population of about 30,000 that swelled to twice in dry season, the city was divided into quarters centred around the main market popularly known as Kurmi. Three classes of professional kolanut traders developed after 1806 namely the Agalawa, the Tokarawa and the Kambarin barebari (Ferguson 1973). These merchants were among the highest income earners (put at GBP36 in 1926 per annum by colonial government) among non-government officials (Ferguson 1973). Kundila was a contemporary of those "highest income earners" of the $19^{\text {th }}$ Century Kano.

Sanda (1992) reports that the man Kundila was born around 1837 at Lalloki ward inside Kano City and died in 1902. The son of Ahmadu and Aishatu (Sanda 1992), his real name was Haruna (Dan'asabe (1987); Sanda (1992)) from Kutumbawa dynasty. An obedient pupil, who was blessed by his teacher, Kundila attended Mallam Sidi's Makarantar allo located in their neighbourhood. He was a contemporary of the Emir Bello who ruled Kano from 1882 to 1893 . He is the legendary that could buy anything, had enormous wealth but with no descendents that has attained fame like the Dantata family. Little is known about Kundila but one Century after his death, people still make reference to his wealth as well as the popular adage Ya gagari Kundila (Kundila could not buy) in Hausaland.

This paper is an attempt at an in-depth studydigging into the characteristics of credit policies and administration mechanisms in the informal financial sector of $19^{\text {th }}$ Century Nigeria. The paper aims at identifying the various projects which attracted lending in the pre-colonial era, the effectiveness of monitoring and control mechanisms in use as well as how cases of defaults were minimised and managed in comparison to the formal sector in the $21^{\text {st }}$ Century.

\subsection{Methodology}

The paper uses both documentary research and interview methods for data collection. Literature was reviewed to explore findings and opinions of researchers within and outside nigeria on the characteristics of informal financial system, lending practices and the principles of good lending in the formal financial setting. Findings of unpublished master's thesis in history was also used as lead to the interview conducted. The interview in question started with 
members of the extended family of Kundila that are based in Lalloki ward inside Kano City. Information was also obtained from many other persons in both their individual capacities and in their position as community leaders. Accordingly, those interviewed included a grand child of Kundila's teacher, the ward head of Lalloki, the village head of Kundila village in Shanono local government of Kano state, three businessmen and other men who were in one way or the other associated with Kundila's time.

Because of the qualitative nature of the information gathered, data presentation takes a narrative approach. Consequently, data analysis is based on both inductive and deductive reasoning. Interpretation of findings is guided by the modern principles of lending and credit administration as reviewed in the literature.

The study covers the entire life of Kundila with particular emphasis on his lending policies and credit administration. However, the paper did not trace, access, review or present information from the books of account of Kundila. This is because the author does not consider it feasible given the scanty nature of information pertaining to the man.

\section{Literature Review}

Aryeetey and Udry (1995) define informal finance as embracing all financial transactions that take place beyond the functional scope of banking and other financial sector regulations. They identify three informal finance units namely (1) savings mobilisation units; (2) lending units and (3) savings mobilisation and lending units. They contend that the variation in the type of informal finance units is usually in response to the demand of a distinct clientele defined by them using various geographical and/or socioeconomic criteria. Ekpo and Umoh (2011) state that the informal sector in Nigeria refers to economic activities in all sectors of the economy that are operated outside the purview of government regulation. They contend that these activities are difficult to measure; but, highly dynamic and contribute substantially to the general growth of the economy and personal or household income. They also categorised the informal sector into (i) Productive; (ii) Service; and (iii) Financial subsectors. Ekpo and Umoh note that activities of the informal financial sub-sector are mostly underground, unofficial, irregular, informal, shadowy, and parallel. However, they posit that the informal sector is better placed to absorb unutilised resources which the public sector and the organised private sector are not willing or able to use.

Agundu (2005) on the other hand argues that there is increasing global recognition of informal financial sector because the congregation and aggregation formal financial system cannot capture all surplus and deficit economic units of nations. Qorchi, Maimbo and Wilson (2003) also observe a renewed public interest in the activities of the informal financial sector following increasing press coverage focusing on the putative connection between terrorist financing activities and the informal funds transfer (IFT) system after September 11. They argue that informal financial system flourishes in countries with inefficient financial institutions and restrictive financial policies. They also contend that IFT limits the significance of economic data by underestimating the factors that affect certain economic aggregates, including national accounts thereby reducing reliability of statistical information available to policymakers. They conclude that IFT systems have negative fiscal implications for both remitting and receiving countries while they are not subject to taxes on income and services. They however recommend that informal financial dealers should be registered and be made to keep adequate records transparently while policymakers should address economic and structural weaknesses that encourage transactions outside the formal financial systems as well as the weaknesses in the formal financial sector itself.

In contrast to the opinion expressed by Qorchi, Maimbo and Wilson (2003), Li (2007) notes that informal financial system plays a complementary role to the formal financial system by servicing the lower end of the market and uses its monitoring and enforcement advantage to ensure repayment. He observes that informal financing in rural areas of China exists mainly in loan broking, providing lending (including usuries), underground banking, trade credit, pawning house, etc. He concludes that attempt to suppress informal financial system will only make it to operate underground and suggests that Government should recognise it as a down-trodden institution which needs to be integrated into the obit of prudential guidelines. Jones et al (2000) agree that formal and informal sources complement each other in determining credit to and deposit making by enterprises in Ghana. They contend that more informal sources of credit are preferred for obtaining start-up capital with working capital obtained in various ways from traders, moneylenders, friends, relatives including spouses, own profits and proceeds and suppliers credit. They assert that advantages of linkage between formal and informal financial institutions with respect to lending arrangement includes substantial earnings, high repayment rates and high proportions of group members graduating to direct relations with the financial institutions. They also note that it is equally cost-effective lending to large number of indirect clients by formal financial sector.

Pagura and Kirsten (2006) also states that less formal financial institutions serves as linkage partners between formal financial institutions and the rural clients. They note that some linkages are spontaneous and market driven like lending to cooperatives and NGOs but other linkages are sponsored such as when apex institutions are created for 
lending to small rural retail or institutions while some emerged out of compliance with regulations. They observe that whereas there are linkages that are permanent, others have natural lifecycle. On the other hand, Floro and Ray (1997) assert that expansion of linkages between formal and informal financial institutions presents an ambiguous effect on strategic cooperation among the major lenders and conclude that any credit subsidy or targeting programme by government may only increase the ability of the informal lenders to capture rents accruing from such a programme. However, Demirgüç-Kunt (2010) believes that reputation and relationship-based informal financing and governance mechanisms are likely to play a limited role in supporting the growth of private sector firms and unlikely to substitute for formal mechanisms. Conversely, Gahadassi (2000) opines that the proponents of financial repression approach do not view informal credit markets as an alternative source of financing even for developing countries. She observes that there is a clear transaction relationship between informal and formal financial sector operators whereby informal lenders have access to banks by depositing their funds at the banks and cater to different segments of the financial markets due to their differential comparative cost advantage by lending to high risk borrowers without collateral while the banks concentrate on less risk borrowers with collaterals. She concludes that information and its quick dissemination are the essence of a money lender's security such that a merchant turned down independently by two different lenders is also confronted by a third lender with this knowledge within the hour; and this she notes; is consistent with the new institutional economics. However, Aryeetey and Udry (1995) assert that the success of informal lenders in achieving high repayment rates cannot be attributed to intensive monitoring activities. They argue that lenders react to delinquency and default by simply going to the homes and businesses of their clients to deliver verbal warnings.

Jhingan (1998) posits that lending to a beneficiary is a form of assistance but it serves also as a means of saving as well as an investment avenue to the creditor. That lending is assistance when it has helped to alleviate the financial difficulties of the beneficiary without putting him into perpetual dependency by means of obligation not only to pay more than he received but also to be unable to liquidate that obligation within a reasonable period of time. Lending serve as a means of saving when the debtor payback the amount at an agreed proportion within agreed time especially when the value has not been eroded and the creditor is able to put the sum into beneficial use. Lending becomes an investment when returns are earned (profit or loss) by the creditor commensurate with the initial sum and in reflection of the true operations of the business. Thus, Pitchard (1958) notes that for an economy, good or bad credit depends on many elements including the extent to which the factors of production are employed, whether or not the extension of credit will increase the ability of the borrower to repay the obligation, the level and movement of prices, and the source of credit.

Henderson (1988) argues that sensible lending involves making a reasonable attempt to measure risk and decide whether the return to be made justifies the risk being taken. Consequently, he advances five major methods of reducing lending risk including: insurance cover, staff training, setting lending limits, monitoring lending and spreading risk by measuring exposure to different industries or countries.

In order to guide decision-makers, Henderson (1988) also devices six mnemonics for lending namely: Purpose, Amount, Period, Expertise, Repayments and Security (PAPERS). He further proposes two alternative memory tricks for decision-makers including PARSER (Person, Amount, Repayment, Security, Expediency and Remuneration) and CAMPERI (Character, Ability, Margin, Purpose, Amount, Repayment and Insurance). Aremu, Suberu and Oke (2010) on their part enumerate that applicants income, outstanding debt, financing assets, duration on the job, lending history of the customer, collateral owned, type of bank account are some of the factors to consider in determining lending. In fact Safety, Liquidity, Purpose, Profitability, Security, Spread and National Interest, Suitability, etc are generally considered as the principles of good lending which every banker follows when appraising an advance proposal. Assurance that the loan is safe, which is applied for the intended purpose, capable of generating profit and that the money will definitely come back on demand or in accordance with agreed terms of repayment with good security to fall back on default is crucial. Good lending also requires spreading into different industries and to meet national interests. Jhingan (1998) also characterises essential factors for credit into six namely: i) confidence; ii) time element; iii) transfer of goods and services; iv) willingness and ability; v) purpose of credit; and, vi) security.

Shapiro, Solomon and White (1963) on their part argue that lending or credit serves the lender, the borrower and the needs of trade. They opine that the use of credit and debt permits capital formation on a large scale and thus encourages technological progress and economic growth. They identify three broad categories of credit that are classified under "use", "maturity" and "type of debtor". That credits are granted for investment, commercial and consumption uses. On the other hand, credit will mature either in long-term, intermediate, short-term or on demand. Finally, credit is granted to public and private sectors. However, Dunaway (1997) asserts that a good lender will loan for everything because he sees an integrated operation that has more value as a package than it does as separate 
parts. He distinguishes between cash flow and collateral lenders. He explains that cash flow is the ability to pay off the loan and keep the operation going while collateral is the ability to pay off the loan by selling the assets and getting out of business. Dunaway points out that a good lender is capable of providing services beyond loaning money - like management assistance and with variety and flexibility in financing terms as well as high enough lending limit that can accommodate borrower's expansion.

Ji (2009) contends that the existence of informal rules based on relationships of trust such as reputation, geographical or family ties has not only helped financing the Small and Medium Enterprises (SMEs) in China which were suffering from asymmetry in information it has also worked as an efficient engine to drive the growth of SMEs. $\mathrm{He}$ discovers that financial statements of SMEs were hardly trusted by formal financial sector because the documents were generally inaccurate and cannot be used for monitoring after lending to check whether business activities led to default in loan repayment. Corroborating the findings by Ji (2009), Ritz (2008) refers to a survey by the Commercial Law League of America which revealed that after three months, the probability of collecting delinquent accounts drops to $73 \%$ while after 6 months, collectability drops to $50 \%$; and after 1 year, collectability is just $25 \%$. Ritz then recommends that it's essential to have a plan in place in order to follow up on every past due account. Ritz (2008) survey also shows that only about half of all credit departments have a written credit policy in place - and only one-quarter of those regularly review that policy. He contends that thoughtfully designed mission statement is basic to a functional credit and collection policy. He also stresses the need to establish goals which are linked to targets and monitored and measured against established metrics thereby functioning as drivers to improve receivable management. Ritz therefore suggests the establishment of Credit Department and laid down policy for risk assessment and the level of authority of every credit officer.

\section{Capital Formation by Kundila}

Typical of makarantar allo pupils, Kundila's enterpreneurial development started at the age of twelve by hawking water and then a combination of commodities on commission bases. Because of his high marginal propensity to save (MPS), he was already independent at the age of twenty-two years after accumulating enough capital (Dan'asabe 1987). Dyed cloth, white cloth, black turban and dankura were among the popular wares in his business. His interregional exposure began at the age of thirty when he joined a Gwanja (modern Ghana) bound caravan. He made a lot of profit through cutting overhead costs and profit ploughing back to increase the working capital (Dan'asabe 1987).

At forty, Kundila was ready to diversify his business. He was into spinning, weaving, leather works, smithing as well as dyeing services sourcing all the needed raw materials from his subsidiaries (Sanda, 1992). His interregional trade was managed by trusted slaves while taking part as a sleeping partner in some cases (Dan'asabe 1987). The marketing outlets were accordingly extended to Azbe, across the south Sahara desert, Borno and area beyond, Adamawa, Bauchi, Nupe, Borgu, Libtaku, Jega, Adar, Katsina and Zaria (Kundila, 1992).

\section{Lending Policy of Kundila}

Kundila was a renowned capitalist, a shrewd investor and a financier par excellence. He financed anything from political programmes to business undertakings. One prominent incident in the field of politics was the financing of Prince Bello's mission for confirmation at Sakkwato the new emir of Kano. Kundila disbursed one Keso (Gwadabe 1992) of cowries to Prince Bello. A Keso contained one thousand cowries which was equivalent to Great Britain's four shillings and two pence (GB4s: 2d) after the invasion of Kano by the British in 1903.

The credit granted for the political project of Prince Bello was not backed up by any collateral except his own goodwill. While the Emir did not indicate intention to refund the one Keso of cowries granted him, Kundila did not also asked for repayment. Thus, there was no predetermined interest rate nor was the mode of payment and duration spelt out. But as a shrewd investor, it was not to be expected that Kundila could have given the money free to Prince Bello. This manifested when Kundila was invited by Prince Bello after being turbaned in Sakkwato as the new Emir of Kano and was asked by Emir Bello to request for any alfarma (favour). Kundila simply replied:

"Whenever a hawker or any trader around the Kurmi market is caught on a minor offence committed, if on investigation he is found to be one of my agents, I beg your Royal Highness to give a standing order that he should be released".

Kundila's request sounds small but it was loaded with a lot of economic gains which we will examine under implications of the findings.

Kundila also granted trade and consumption credits. These types of credits were granted based on seven lending principles: 
i) Personality: a prospective borrower, trade debtor or lessee must either be a direct relation of Kundila, an established customer or his relation guaranteed by the customer in question or a man of high integrity.

ii) Control of margin: beneficiaries of trade credit must sell the items at an agreed profit margin.

iii) Pledge redemption: this requires payment as at and when it was due. Consequently, trade debtors must render their accounts, tenants were to pay rent and money debtors must liquidate on due date.

iv) Commodity standard: consumption loan was based on a "buy and sell back" system. Accordingly, prospective consumption loan beneficiaries would identify item inside Kundila's shop to take on loan that would cover the amount of money they needed and then sell the commodity back to him at a discount in order to realise cash.

v) Witness: all credits were to be witnessed by at least two persons one each from both sides of the parties to the credit.

vi) Promptness: credits must be sought only when needed and released promptly after all agreements have been concluded.

vii) Net-net: all lease agreements were "net-net" in nature. This meant that lessees were to bear the burdens of maintenance and improvement of the quality of the asset e.g. farmland, payment of Zakkah on yield and any other taxes imposed by the Emirate. All lease contracts was for a season with rental charge known as Galla payable at fixed proportion of the yield usually one-tenth. There were also few cases of upfront cash payment known as Lada. Kundila was not involved in leverage leasing but he was very active in direct lease as well as sale and lease back systems.

\section{Method of Credit Administration}

Management of credits generally took a routine system. Beneficiaries knew the implications of default and Kundila had an effective monitoring system. Bad debts were either written off or legal actions were instituted against any defaulters. Where bad debts were written off, it had the implication of blocking all avenues to the debtor for any future credit within and outside the Kano Emirate. Such individuals could only purchase in cash and, sometimes, not even from the major businessmen. There were very rare cases of legal actions against loan defaulters because of the bondage of personal relationship and the image of Kundila himself. Other credit administration measures include:

\subsection{Monitoring}

Kundila had secret agents that were assigned to monitor the activities of specific number of loan beneficiaries and made reports. Their duties included monitoring of selling price in order to know the margin of the traders as well as their stock balances.

\subsection{Stock Returning}

Traders could return goods when prices fell in the market and receive new allocation from stocks produced or obtained at lower costs. Alternatively, they could give account of sales and put the balance aside until prices rose again while new allocation at lower cost was issued. The aim of this control mechanism was to block as much as possible any chance of manipulation by traders due to price fluctuations.

\subsection{Auction}

Loan defaulters may have their assets confiscated and auctioned. This measure was taken when all efforts to recover the loan had failed. Assets valuers were usually called upon to assess and determined the market value of the property in the presence of witnesses from both parties. Any surplus over outstanding debt was remitted to the debtor while auctioning additional property were made to make up for any short falls.

\subsection{Tamirgina System}

This was a concept of debt roll over. It was applied only on consumption loans. Tamirgina meant "roll over" which carried with it 100 percent interest charge.

\subsection{Cancellation}

Defaulters ran the risk of severing their relationship with Kundila and all other major traders. The ability of a debtor or lessee to honour his loan obligation automatically guaranteed renewal/or expansion.

\section{Implications of Findings}

It has been established from the study that lending principles had been in place and a model of credit administration practice was put up to hedge against loss in the informal financial sector of Nigeria before the coming of Europeans into the interior. 
We noted that the one Keso advanced by Kundila was not refunded; instead, he asked for a favour that his agents caught for minor offences should be released. The financial implications of Kundila's request were many including:

\subsection{Exemption from Payment of Fine}

offences whether minor or big carry some fines on conviction or even a jail term. With a standing order by the Emir to immediately release all Kundila's agents caught for minor offences around the busy Kurmi market, Kundila succeeded in getting a waiver. Considering his large number of agents (being the riches person at his time) the fines over the years was far above the one Keso he gave to the Emir including any interest on it even when Tamirgina condition is applied.

\subsection{Time Advantage}

Since the mere identification of the offender as agent of Kundila brought the case to an end, no delay is caused to the agent through prosecution proceedings. The time saved allowed the agent to continue hawking Kundila's wares thereby achieving high sales turnover and invariably profit.

\subsection{Perpetual Advantage}

Kundila was to enjoy the waiver for life (until his death or that of the Emir). This advantage also covered any upward review of the fine being paid for minor offences. Furthermore, other hawkers may enjoy the waiver under the pretext of agents of Kundila while the market inspectors may release other hawkers without trial under the guise that they were Kundila's agents. It was also possible for market inspectors to manipulate major offence cases as minor and waiver to be granted.

The canons of lending of Kundila show how sensitive he was about business risks. Those lending policies measured well with modern principles of credit. It is particularly within the purview of the 4Cs of lending. Not only the character and capability of the prospective borrower had to be taken into cognisance, there was to be a collateral (or guarantor) and competence of the borrower to manage the loan.

The one Keso advanced to Prince Bello by Kundila during his mission to Sakkwato could be misunderstood that he sought for the amount in order to enable him bribe his way for installation as Emir of Kano. However, considering the fact that Prince Bello and his entourage were to make their journey to and from Sakkwato on animal back with majority walking on foot, Prince Bello needed that much travelling allowance to be able to maintain himself and his company of slaves, friends, scholars and other well-wishers during the journey.

Kundila's credit administrative measures on the other hand were adequate to hedge him against foreseeable cases of default. His "secret agents" resemble the credit officers in modern banks. However, while in the case of the latter they appraise credit proposals and make recommendations as to approve or reject loan applications, the former were limited to monitoring and reporting borrowers' performance only. Nevertheless, Kundila's secret agents may be trustworthy than the credit officers in modern banks because of the different level of morality. Increase in fraud cases in banks today may be a pointer to the high level of moral decadence in modern society. Large amount of money is being spent in fraud prevention through installation of gadgets and the organisation of workshops and conferences for bank portfolio managers on fraud prevention only to discover insider connections to recent fraud cases involving the same managers that attended those courses.

The provision to return goods when prices fall in the markets was only possible because the economy was a simple one at the time and the nearly monopoly enjoyed by Kundila as a source of supply. Such arrangements will work with great difficulties today. Also, the privilege of setting aside stock balance affected by price change can be abused in this our time as evident from the practices of some distributors and sub-distributors of manufactured goods in Nigeria. Again, it is inconceivable these days to block all avenues of credit facilities or sources of supply because of default in a single source. Different banks and manufacturers now have different criteria of evaluating the credit worthiness of clients. Sometimes their major consideration may be political which of course only stresses on one of the credit lines of Kundila.

Until in the early 1990s when interbank lending rate reached about 120 percent in Lagos area, no bank or any other financial institution charges up to 100 percent interest on loan. Thus, Kundila's Tamirgina system is not applicable in the modern system especially if market forces are allowed to function without distortion. Tamirgina practice is equally rare even among moneylenders.

Kundila had a fair way of calculating rental payments on lease assets. Rent was a proportion of output. Where rent is paid upfront, the rent was arrived at based on the quality of the asset to be leased. These arrangements are in sharp contrast with what obtains in modern leasing firms where rental payments are tied to balance of the principal instead 
of output or quality of the asset. Probably this is one of the reasons why modern leasing industry in Nigeria is still grossly underdeveloped.

\section{Conclusion and Recommendations}

This study finds that Kundila raised his initial capital by saving from commissions he earned as a salesman. He started his own business as a retailer then a wholesaler and graduated into production of goods and services. He ran an integrated business empire sourcing raw materials and mercahndise from subsidiaries thereby making the output of one entity serving as input for another.

The study also notes that there is universality in the characteristics of informal financial sector. In fact, there is no major difference between lending policies and credit administration systems of $19^{\text {th }}$ Century pre-colonial and $21^{\text {st }}$ Century post-independence Nigeria. Even the products do not significantly differ. Rather, it is basically the structure, language of communication, paper work and the unit of account in use that differs. Financial managers have always been sensitive to risk and therefore devised good credit management strategies to address loan and defaulters. However, there was fundamental difference in the legal framework under which loans were granted. While it was Islamic legal system in those days, today's modern businesses operate under secular legal system. The difference essentially lies in the degree at which legal matters are dispensed with in courts.

However, contrary to the assertion by Aryeetey and Udry (1995) that success of informal lenders in achieving high repayment rates cannot be attributed to intensive monitoring activities and that lenders react to delinquency and default by simply going to the homes and businesses of their clients to deliver verbal warnings, Kundila had a systematic way of monitoring borrowers and audacious approach to crredit administration and loan recovery.

The following recommendations are considered to be useful to government, businesses and society in Nigeria and other developing countries.

1. Government should integrate informal financial sector into the modern economy so as to reap the benefits of the country's rich heritage.

2. Modern leasing firm should borrow a leaf from the leasing methods of Kundila to accord small and medium scale enterprises the opportunity of acquiring sophisticated machineries and equipment. This will increase aggregate production and assist government in achieving rapid economic growth and development in the economy.

3. Manufacturing firms in the country can have a sustained growth if they adopt the strategy of establishing subsidiaries where large part of their raw material needs could be sourced instead of depending on outside sources especially from overseas.

4. The re-introduction of Sharia legal system in some states of the federation provides alternative legal framework where cases can be taken for adjudication. Government should encourage firms and individuals to utilise the different legal systems in order to reduce delays and long quies in courts for quick dispensation of justice. No country can develop if its legal system create bottlenects by keeping cases in courts for over a decade without judgement.

5. There should be continuous ethical re-orientation to greatly minimise cases of betrayal among Nigerians. One way to do this is for leaders and other people in position of authority to live an exemplary life. Those who embezzled money should face the full wrath of the law. Plea bargain and hiding under bankcruptcy theory should be discouraged.

\section{References}

Aremu, O. S., Suberu, O. J., \& Oke, J. A. (2010). Effective Credit Processing and Administration as a Panacea for Non-Performing Assets in the Nigerian Banking System. Journal of Economics, Vol. 1 No. 1, Kama-Ray.

Asli Demirgüç-Kunt. (2010). Can Informal Finance Substitute for Formal Finance? www.blogs.worldbank.org/../505

Bob Dunaway. (1997). Six Characteristics of a Good Lender. www.nationalhogfarmer.com.

Cong Ji. (2009). Chinese Informal Financial System and Economic Growth - A Case Study of China's Small and Medium Enterprises. Public Policy Review, Vol. 5, No. 1, Policy Research Institute, Ministry of Finance, Japan at www.academic.research.microsoft.com/Pub.

Credit Administration, Measurement \& Monitoring Process. www.scribd.com/doc/52328136/7/CREDI.

Dan'asabe, A. U. (1987). Comparative Biographies of Selected Leaders of the Kano Commercial Establishment, M. A (History) Thesis, Department of History, Bayero University, Kano - Nigeria. 
Ekpo I. A. H., \& Umoh 0. J. I (2011). The Informal Sector Today,. www.onlinenigeria.com/economics

Ernest Aryeetey, \& Christopher Udry (1995). The Characteristics of Informal Financial Markets in Africa,. Paper Presented at the Bi-annual Research Conference, African Economic Research Consotium, Nairobi, Kenya.

Ferguson, D. E. (1973). 19 $9^{\text {th }}$ Century Hausaland: Being a Description by Imam Imoru of the Land, Economy and Society of his People, Ph.D. Thesis.

Holloway, S. (1992). Air Finance, Pitman, London.

Howard Jones, et al. (2000). Linking Formal and Informal Financial Intermediaries in Ghana - Conditions for Success and Implications for RNR Development. Natural Resources Perspective, No. 61, Overseas Development Institute, London.

Informal Financial Systems in West Africa. Developments and ... www.afraca.org/publications/453Inno.

Jhingan, M. L. (1998). Money, Banking and international Trade, $5^{\text {th }}$ Revised and Enlarged Edition, Vrinda Publications (P) Ltd., Delhi.

Lot, J. Y. (1981). Domestic and International Banking Services, Nigerian Institute of Bankers and Macmillan Nigeria Publishers Ltd., Lagos.

Lovejoy, P. E. (1973). The Hausa Kola Trade (1700 - 1900). A Commercial System in the Continental Exchange of West Africa, Ph.D. Thesis.

Maria Pagura, \& Marie Kirsten. (2006). Formal-Informal Financial Linkages - Lessons from Developing Countries at www.bwtp.org/pdfs/arcm/Pagura.pdf.

Maria Sagrario Floro, \& Debraj Ray. (1997). Vertical Links Between Formal and Informal Financial Institutions. Review of Development Economics, Vol. 1 No.1, Blackwell Publishers Ltd, Oxford at www.citeseerx.ist.psu.edu/viewdoc/download.

Maryam Gahadassi. (2000). Informal financial institutions in bazaar, www.cemoti.revues.org/634.

Meghana Ayyagari, Asli Demirgüç-Kunt, \& Vojislav Maksimovic. Formal versus Informal Finance: Evidence from China,. www.rfs.oxfordjournals.org/../3048.full.

Mohammed El Qorchi, Samuel Munzele Maimbo, \& John F. Wilson. (2003). Informal Funds Transfer Systems: An Analysis of the Informal Hawala System,. www.imf.org/../index.htm.

Pitchard, L. J. (1958). Money and Banking, University Press Cambridge, Massachusetts, USA.

Prince Umor C. Agundu. (2005). Reengineering Nigeria's Informal Financial Sector for Macroeconomic Synergies. Journal of Financial Management and Analysis, Vol. 18, www.papers.ssrn.com/sol3/papers.cfm.

Principles of Good Lending Every Banker Follows - Loans. www.kalyan-city.blogspot.com/2010/09/pr..

Reengineering Nigeria's Informal Financial Sector for ... www.papers.ssrn.com/sol3/papers.cfm.

Riki-Lee Ritz. (2008). Six Essential Elements of an Effective Credit and Collections Policy,. www.credit-to-cash-advisor.com/Arti...

Shapiro, E., Solomon, E., \& White, W. L. (1963). Money and Banking, Dryden Press, Hinsdale, Illinois.

Zhao Li. (2007). Research on Informal Finance in Rural Area of China, School of economy and Management, Zhongyuan University of Technology, ZhengZhon, China. 